\title{
ON THE OBSERVATION, CHARACTERISATION, AND PREDICTIVE GIS MAPPING OF STRONG GROUND SHAKING FOR SEISMIC ZONATION
}

\author{
(A CASE STUDY IN THE SAN FRANCISCO BAY REGION, CALIFORNIA)
}

\author{
R. D. Borcherdt1
}

This paper was presented as a keynote address at the Pacific Conference on Earthquake Engineering, Auckland, November 1991.

\section{SUMMARY}

Tragic earthquakes of the last decade in Mexico, Armenia, and the United States have re-emphasised the importance of local geologic site conditions in determining amounts of damage and consequent loss of life. Extensive data sets in the San Francisco Bay region on strong earthquake ground motions, the damage distributions from past earthquakes, and geologic materials provide the basis to quantify site condition effects for purposes of earthquake hazard mitigation. These observational data are reviewed and analysed to provide methodologies for the characterisation and predictive mapping of potential variations in strong ground shaking for seismic zonation. The methodologies are based on existing geologic maps. They provide a method for seismic zonation applicable to many urbanised seismic regions of the world.

\section{INTRODUCTION}

Earthquake losses originate predominately from strong ground shaking, either directly from shaking-induced failures of man-made structures or indirectly from shakinginduced ground failures associated with liquefaction, landsliding, or water inundation. In general, strong shaking decreases in amplitude with increasing distance from the source; however, strong evidence indicates that local geologic deposits, especially "soft soils", may significantly amplify the level and duration of strong ground shaking, thereby increasing its damage potential. Earthquakes of the last decade, especially those affecting Mexico City, Leninikan, Armenia, and the San Francisco Bay region, California tragically demonstrated this important lesson. Life and property losses from these earthquakes have stimulated renewed interest in the development of improved hazard mitigation measures to account for the influence of local geologic deposits. As an example, legislation was recently passed in the state of California (Seismic Hazard Mapping Act, $A B 3897,1990)$ mandating that guidelines and priorities be established for seismic zonation maps that identify special study zones for ground shaking, liquefaction, and landsliding.

Seismic zonation to account for geographic variations in strong ground shaking with corresponding land-use policies can be a significant step towards mitigating the effects of earthquakes in densely urbanised regions. However, a major issue with respect to the preparation of such maps for ground shaking has been the nature of the amplification characteristics of "soft" soil deposits at the higher strain levels associated with damaging levels of ground motion. Recordings of strong ground motion from the recent Loma Prieta earthquake and those previously obtained in Mexico City help resolve this issue.

This paper reviews the observations and evidence concerning the seismic response of local geologic deposits in the San Francisco Bay region, including that provided by the strong ground motion recordings of the Loma prieta earthquake. A method for characterising variations in ground response on a regional scale is presented. The method is based on correlations between observed ground motions, earthquake intensity, and extensive sets of shear velocity and geotechnical data. These characterisations and a geographic information system (GIS) are used to illustrate a method for preparation of seismic zonation maps for strong ground shaking.

Geologic, geotechnical, and seismic data sets are relatively complete for the san Francisco Bay region, compared to those available in many other urbanised areas. These data provide an important basis for quantifying the response characteristics of a wide variety of geologic deposits and an important basis for developing empirical relations for extrapolation to other regions. Data sets available include: intensity data from both the 1906 and 1989 earthquakes, weak and strong-motion recordings, microtremor measurements, detailed geologic mapping, and shear velocity logs. These data and the broad spectrum of geologic units in the region, ranging from hard rock to thick sections of 
alluvium to very soft water-saturated clay deposits imply that derived results are applicable to other urbanised regions at high seismic risk.

\section{GEOLOGIC DEPOSITS}

San Francisco Bay is located in a basin about $15 \mathrm{~km}$ wide bounded by the active San Andreas and Hayward fault zones. The region is characterised by a wide variety of geologic deposits in close proximity. The deposits range in age from more than 100 million years for rocks beneath the hills to esturine mud and clay deposits still being deposited at present along the margins of the bay.

Geologic maps of special importance for seismic zonation in the region are those compiled for flatland deposits [18] and hill side materials [27]. These maps identify and differentiate units on the basis of physical properties and geologic characteristics at scales useful for planning purposes $(1: 62,500 ; 1: 125,000)$. The maps differentiate the hill side materials into some 31 units of varying age, genesis, structure, thickness, and physical properties. They differentiate the flatland deposits into some seven units depending on age, depositional environment and physical properties. Engineering terms of "rock" and "soil" are used herein to refer, respectively to hill side materials and flatland deposits.

The hill side material units can be generalised into some six generalised units which appear on geologic maps as Quaternary and Tertiary sedimentary rocks of the Santa clara and Merced formations (QTs), Tertiary and Mesozoic sedimentary rocks (TMzs), cretaceous granitic rocks $(\mathrm{Kg})$ and cretaceous Jurassic Franciscan Complex (KJf), Figure 1[10]. Small outcrops of serpentine ( $\mathrm{sp}$ ) are in general surrounded by melange of the Franciscan complex and generalised herein as part of the Franciscan Complex [10].

The flatland deposits can be classified into two general categories, Quaternary alluvium (Qal) and Quaternary Holocene bay mud (Qhbm; Figure 1). The alluvium is differentiated according to age (Pleistocene, Qpa and Holocene, Qha). The Holocene alluvium is further subdivided into units of predominantly fine-(Qhaf), medium-(Qham) and coarse-(Qhac) grained materials, and beach and dune sands (Qhs) [18].

The alluvial unit is comprised of materials ranging from well-sorted sands to coarsegrained clay, silty clay, sandy gravel to poorly-sorted irregularly interbedded clay, silts, sands and gravels. The unit reaches maximum thicknesses of 400-500 metres in the south bay region (Figure 1). Shear wave velocities range from $150-220 \mathrm{~m} / \mathrm{s}$ for dune sands to $420-750 \mathrm{~m} / \mathrm{s}$ for sandy gravels [12]. The unit of most concern for its potential influence on strong ground shaking is the Holocene bay mud unit (Qhbm). This unit located along the margins and beneath the bay generally overlies the alluvial unit. It is comprised on unconsolidated, water- saturated, dark plastic clay and silty clay with well-sorted silt and sand dunes in some areas. It may contain more than 50 percent water by weight and has characteristically low shear-wave velocities $(55-115 \mathrm{~m} / \mathrm{s}$; [12]). It reaches maximum thicknesses near $35 \mathrm{~m}$ along the margins of the bay. In urbanized areas the bay mud is overlain by man-placed fills (Qaf) generally stiffer with slightly higher shear velocities (160-

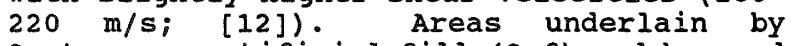
Quaternary artificial fill (Qaf) and bay mud (Qhbm) are designated $\mathrm{Qm}$ on generalised geologic map (Figure 1).

A geographic information system (GIS) is currently being used to compile and archive data bases in the region pertaining to mapped geologic material units, topography, surface faults, and seismicity [28]. The geologic data is based on published maps for flatland deposits [18] and hill side materials [27], which together differentiate some 38 material units $[28]$.

The data sets are being compiled as a suite of map layers registered to a topographic map at a scale of $1: 125,000$ (US Geological Survey, 1970). Compilations and analyses are being conducted using a commercial GIS termed ARC/INFO and an institute-developed user interface termed ALACARTE[28]. Map elements are stored in vector mode as points, lines, and polygons to which attributes of interest are assigned. These data bases form the basis of the predictive methodologies presented here.

\section{OBSERVED INFLOENCES OF LOCAL GEOLOGIC DEPOSITS ON EARTHOUARE SHARING AND RESULTANT DAMAGE}

Information on the distribution of damage from past earthquakes and quantitative measurements of ground motion are necessary to develop empirical relations needed to anticipate the effects of future earthquakes. Information on the damage distribution for the 1906 and 1989 earthquakes together with available groundmotion data in the San Francisco Bay region provides a special opportunity for the development of such relations.

\section{Earthquake Damage}

The great 1906 earthquake was the first major earthquake to yield well-documented evidence showing the influence of local "soil" deposits on earthquake damage. In the "Report of the state Earthquake Investigation Commission" [22], J 0 wood [28] concluded that "This investigation has clearly demonstrated that the amounts of damage produced by the earthquake of 18 April 1906 in different parts of the city and county of San Francisco depended chiefly upon the geological character of the ground. Where the surface was of solid rock, the shock produced little damage; whereas, upon made land great violence was manifested. In this part of the zone of destruction (Lower Market street area of San Francisco), change in distance from the fault clearly did not influence the gradation in intensity, so much as did change in character of the ground". 


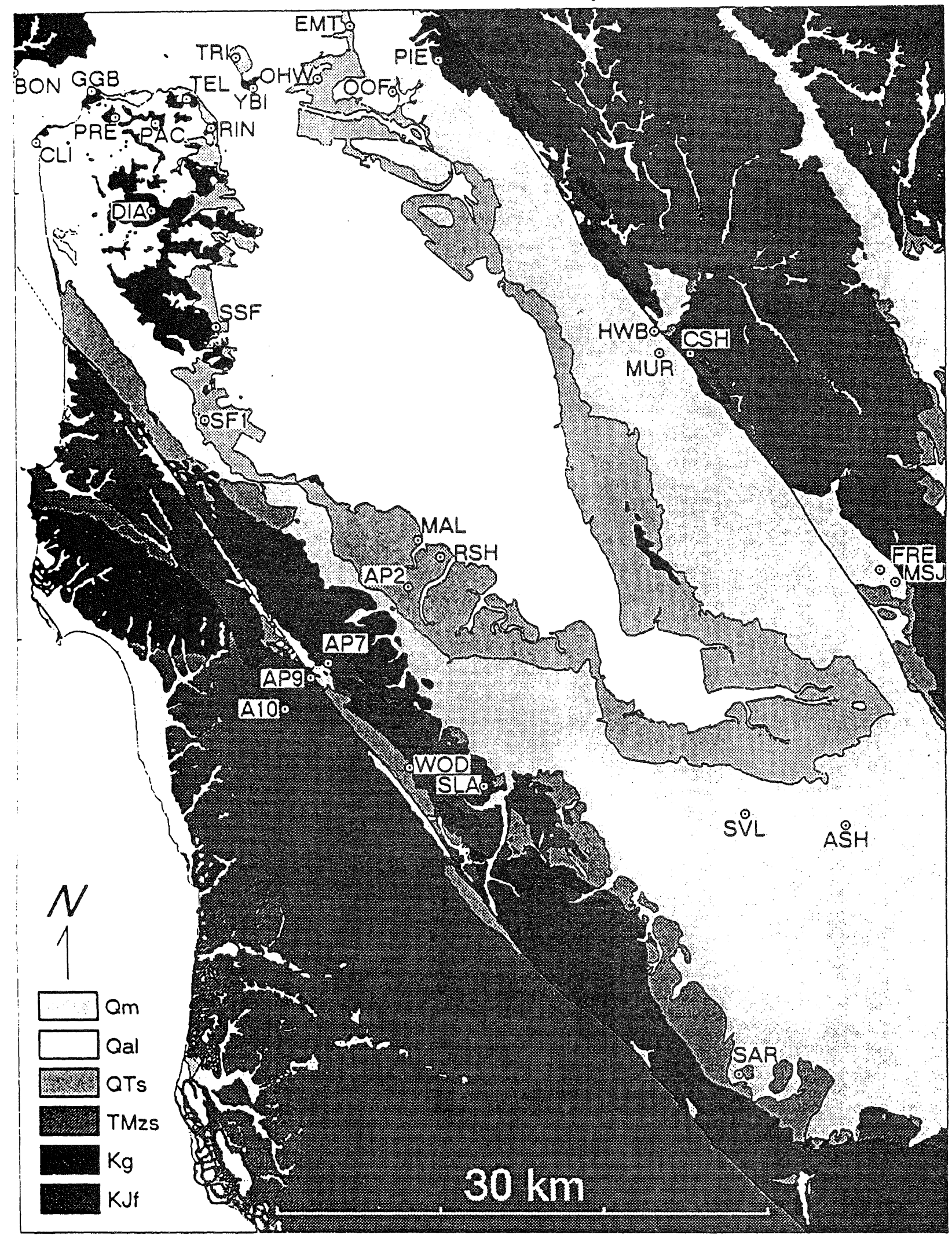

FIGURE 1 GEOLOGIC MAP BHOWING LOCATIONS FOR 32 OF 34 FREE-FIELD STATIONS, WHICH RECORDED THE LOMA PRIETA EARTHQUARE OF OCTOBER 17, 1989 IN THE SAN FRANCISCO BAY REGION, AND GENERALISED GEOLOGIC UNITS (see Table 1; Lajoie in Borcherdt et al, 1975). 
In general, the ascribed intensity distribution for the 1906 earthquake shows a strong correlation with the corresponding distribution of various geologic deposits. In general, intensities for a site at comparable distances were found on the average to be 2.4 to 3.0 units higher (1906 S.F. scale) for sites on bay mud and 1.3 units higher for sites on alluvium than those for sites on rocks of the Franciscan complex $[5,10]$. Such correlations between intensity and site geology were reported for 18 California communities affected by the earthquake [22].

The damage resulting from the recent earthquake of 17 october 1989 near Loma Prieta has reconfirmed the role of local soil conditions in influencing the severity of earthquake damage. In an extensive geotechnical survey [25], R B seed and others concluded that "Geotechnical factors exerted a major influence on the nature and severity of ground shaking during the Loma Prieta earthquake. Indeed, the major influence of geologic conditions or "local site effects" on both strong shaking characteristics and resulting damage patterns was one of the most striking features of this event". They point out that a majority of the damage to structures and 80 percent of the life loss occurred at sites underlain by soil deposits. They observe that damage was concentrated at a few relatively distinct sites comprising less than one percent of the "strongly" shaken region. outside the immediate epicentral region, the areas of intense damage are underlain by "soft" soils.

A type of structure known to be especially vulnerable to earthquake shaking is unreinforced masonry (URM). Holmes et al. [19] conducted an extensive damage survey of more than 1925 such structures in San Francisco following the 1989 Loma Prieta earthquake. In considering the various building and site characteristics that might correlate with increased damage percentages observed for the structures, they found that "softness" of soil deposit and story height showed the strongest correlation. Damage ratios expressed as percent of replacement value as derived by Holmes et al. are shown as a function of approximate average shearwave velocity for sites underlain by fill and/or Holocene alluvium, pleistocene alluvium or rock (Figure 2). They show that, in general, damage ratios increase with decreasing firmness of the deposit. They show that for buildings with story heights greater than 11 feet, the ratios were about seven times greater for "soft" soil deposits than for rock sites. Testing the null hypothesis that the means for the soil samples were equal to that of the rock sample using the students distribution they found that the null hypothesis could be

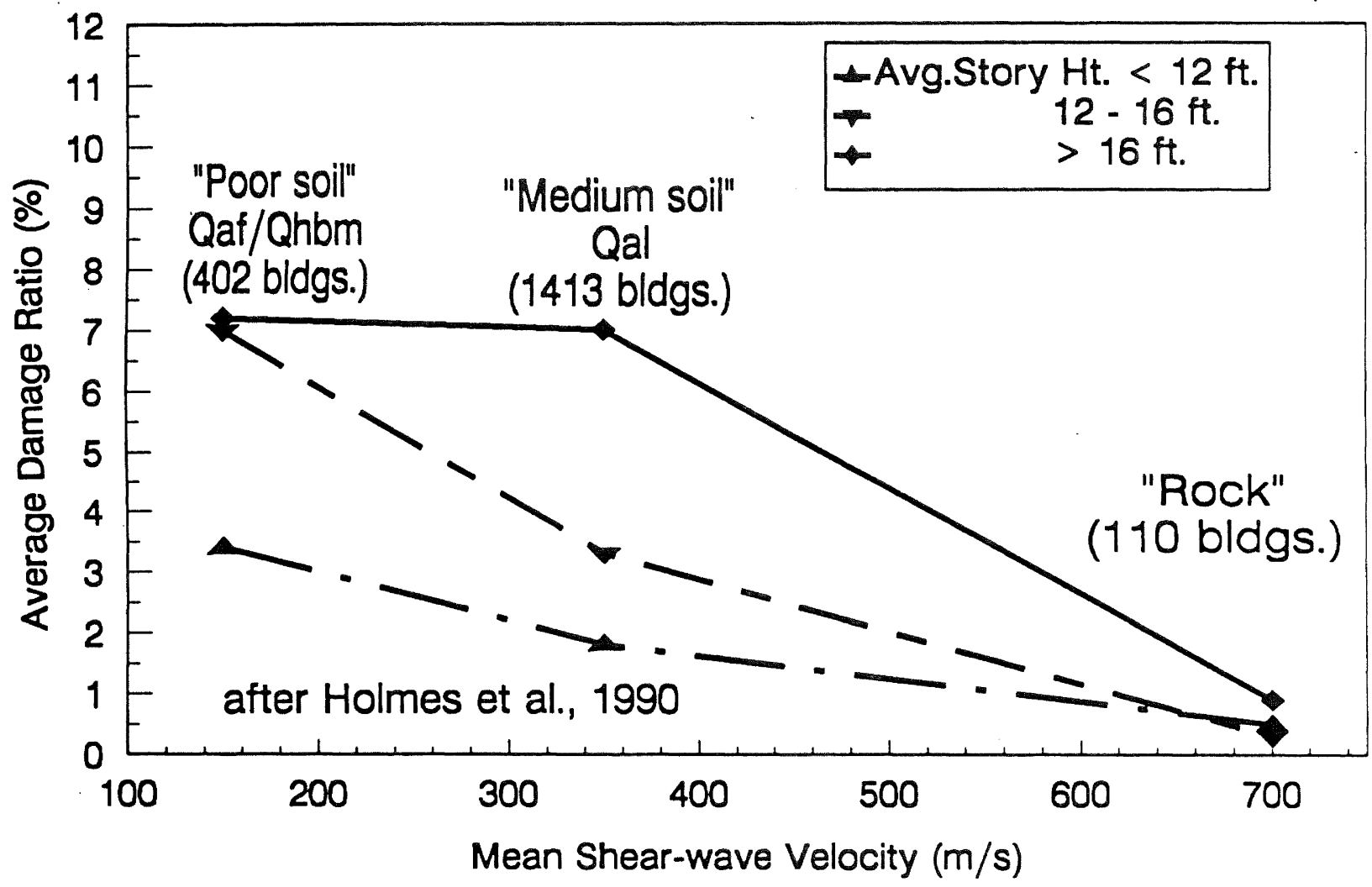

FIGURE 2 AVERAGE DAMAGE RATIO FOR 1925 UNREINFORCED MASONRY 8TRUCTURES IN THE CITY OF SAN FRANCISCO AS COMPILED AND CLASSIFIED ACCORDING TO BTORY HEIGHT AND GEOLOGIC MATERIAL BY HOLMES [19] PLOTTED VERSUS ROUGH ESTIMATE OF BHEAR VELOCITY. THE PLOT 8HOWS THAT THE DAMAGE PERCENTAGE IS 7-8 TIMES GREATER FOR BUILDINGS (8TOREY HEIGHT $>11$ FT) ON "BOFT SOIL" BITES THAN ON ROCK SITES. 
rejected at the 95 confidence level. Their results provide strong evidence that these stiffer but, in general, weaker structures are more vulnerable on soil deposits than on rock sites.

The areas of increased damage to vulnerable structures (including URM) during the Loma Prieta earthquake coincide with many of the same areas of increased damage that were observed during the 1906 earthquake. This coincidence of areas of high damage for the two earthquakes provides strong evidence that damage in future earthquakes can be expected to be concentrated in similar areas unless significant steps are taken to mitigate existing hazards.

\section{strong Ground-Motion Recordings}

The Loma Prieta earthquake provided the largest set of recordings of strong shaking yet obtained on a variety of geologic deposits. These data include six free-field recordins on "soft" clays to augment those previously obtained in Mexico City. These limited data provide critical in-situ estimates of the response of these deposits at the higher strain levels corresponding to damaging levels of motion. These measurements are useful for anticipating the response characteristics of similar deposits in other regions of the world with high seismic risk.

The strong ground motion recordings obtained at 34 sites in the San Francisco Bay region (see Figure 1 for locations) from the Loma Prieta earthquake have been presented and analysed in detail $[4,5,7]$. Results of these analyses are summarised here.

Equiscaled plots of the three components of motion prepared for each site show that, in general, both the amplitude and duration of shaking were amplified by local soil deposits relative to motions recorded on nearby rock sites $[4,6]$. Horizontal motions were amplified more than vertical motions at most "soil" sites; amplification of radial motion exceeded that for transverse motion. The larger amplifications for radial motion were interpreted to be due in part to the influence of earth structure on the propagation of radial energy as SV waves.

Ground motions were of short duration, consistent with relatively rapid bilateral $\left(\begin{array}{ll}\sim & \text { secs }) \text { rupture inferred for the }\end{array}\right.$ earthquake faulting process [21]. Consequently, resulting damage from the earthquake probably was less than would have occurred from a similar event with more complex or unilateral rupture.

Comparison of recorded peak motions at sites underlain by "firm to soft" rocks with those anticipated on the basis of previously recorded strong motion data [7] showed that the peak motions for the Loma Prieta earthquake exceeded previous empirical predictions at most sites. These increased motions were interpreted to be due in part to efficient reflection of seismic energy from the base of a relatively shallow earth's crust $(25 \mathrm{~km}$; $[26,11])$.
Ratios of peak amplitude, computed for each measure of ground motion (acceleration, velocity, and displacement) and each component of motion (vertical, radial, transverse) help quantify the influence of local geologic deposits. The ratios were computed for each site relative to a nearby site located on hard rock and normalised by hypocentral distance (Table $1 ;$ Figure 3). The ratios show that all three measure of peak ground motion were significantly amplified at some of the sites located on the softer soil deposits, with the amplifications for peak velocity and acceleration often exceeding those for peak displacement.

An important influence of local geology at some sites on recorded ground motions was the development of site resonance resulting in narrow frequency bands being amplified by factors as large as 10-20. These resonances apparent in Fourier amplitude spectral ratios $[4,7]$ appear as pronounced peaks for horizontal ground motions recorded at some sites located on alluvium (OOF) and fill over bay mud (EMT, OHW). These resonances are of special interest for earthquake engineering. The ground-motion recordings of the Loma Prieta earthquake indicate that resonances developed at some but not all "soil" sites at ground motion levels sufficient to generate damage. The resulting amplifications as large as 10-20 times over narrow period bands are consistent with those observed in Mexico city during the earthquake of 1985. Such site resonances are of special concern in locations where man-made structures exist with natural resonances whose periods may lengthen into these period bands as strong shaking commences.

As a summary of the influence of local deposits on ground motions, averages of the spectral ratios for the period band $0.2-2.0$ seconds are charted for each of the sites (Figure 4). They are shown for the vertical and average of the radial and transverse components. The average spectral ratios provide a somewhat more stable estimate of the response of local deposits than do ratios of peak amplitude, in that they are less sensitive to variations due to instrument response, source, and propagation path characteristics. They show a tendency to increase with decreasing firmness of the deposit, especially for horizontal motion. Means computed for the average spectral amplifications inferred for vertical and horizontal motion are respectively $(1,1)$ for sites in the Franciscan Complex (KJf), (1.4, 1.5) for sites on Mesozoic and Tertiary rocks (TMzs), $(2.1,2.0)$ for sites on the Santa clara Formation (QTs), (2.3, 2.9) for sites on alluvium (Qal), and $(2.1,4.0)$ for sites on fill over bay mud (Qaf/Qhbm) [7]. These observed amplification suggest that amplification by "soft" soil deposits was a significant contributory factor to the observed concentrations of damage at distances near $100 \mathrm{~km}$ in the San Franciscooakland area.

\section{Heak Ground-Motion Recordings}

An extensive set of comparative groundmotion measurements using weak motions 
TABLE 1 RATIOS OF PEAK AMPLITUDE (ACCELERATION, VELOCITY, AND DISPLACEMENT) FOR RECORDING8 OF BTRONG-MOTION (Z-VERTICAL, R-RADIAL, T-TRANBVERBE) FROM THE 1989 LOMA PRIETA EARTHQUARE IN THE SAN FRANCIBCO BAY REGION (AFTER [7]).

\begin{tabular}{|c|c|c|c|c|c|c|c|c|c|c|c|}
\hline $\begin{array}{l}\text { Station } \\
\text { name }\end{array}$ & code & $\begin{array}{l}\text { H.Dlst. } \\
\text { km }\end{array}$ & $\begin{array}{l}\text { S vel. } \\
\text { avg.,30m }\end{array}$ & Acc-Z & Vel-z & Disp-Z & Acc-R & Vel-R & Isp-R & Acc-T & Vel-T \\
\hline South San Franclsco & SSF & 85 & 910 & 0.92 & 0.88 & 0.82 & 0.53 & 1.10 & 0.97 & 1.08 & $\begin{array}{l}0.59 \\
1.00\end{array}$ \\
\hline Rincon HIII & RIN & 96 & 710 & 0.94 & 0.89 & 1.27 & 1.31 & 0.80 & 1.16 & 1.13 & 1.00 \\
\hline Yerba Buena & YBI & 97 & 710 & 0.90 & 0.95 & 0.78 & 0.76 & 0.86 & 1.20 & 0.79 & 1.09 \\
\hline Paciflc Hoights & PAC & 98 & 710 & 1.03 & 1.36 & 1.57 & 0.74 & 0.92 & 0.60 & 0.81 & 1.32 \\
\hline Diamond Helghts & DIA & 94 & 710 & 1.38 & 1.46 & 0.91 & 1.79 & 1.39 & 0.68 & 1.08 & 1.09 \\
\hline Pledmont Jr. Hlgh & PIE & 94 & 710 & 0.82 & 0.46 & 0.66 & 0.87 & 0.94 & 1.39 & 1.10 & 0.91 \\
\hline MEAN(KJt) & & & 743 & 1.00 & 1.00 & 1.00 & 1.00 & 1.00 & 1.00 & 1.00 & 1.00 \\
\hline STANDARD DEV & ATION & & 82 & 0.20 & 0.36 & 0.34 & 0.47 & 0.22 & 0.31 & 0.15 & 0.24 \\
\hline CSUH Stadlum Grounds & CSH & 73 & 525 & 1.11 & 0.78 & 1.18 & 0.64 & 0.69 & 2.01 & 0.67 & 0.41 \\
\hline Woodside Fire S & WOD & 57 & 440 & 0.97 & 0.92 & 0.85 & 0.56 & 0.98 & 1.75 & 0.72 & 0.84 \\
\hline L 7 (Pulgas Temple) & AP7 & 65 & 435 & 1.34 & 0.91 & 1.06 & 1.57 & $1 . \pi 7$ & 2.43 & 0.89 & 0.88 \\
\hline MEAN ( norm. st & - south & & 467 & 1.14 & 0.87 & 1.03 & 0.92 & 1.15 & 2.07 & 0.76 & 0.71 \\
\hline STANDARD DE & ON & & 51 & 0.19 & 0.08 & 0.17 & 0.56 & 0.56 & 0.34 & 0.12 & 0.26 \\
\hline Clift House & CLI & 101 & 710 & 2.11 & 1.76 & 1.13 & 1.72 & 2.38 & 1.86 & 1.09 & 1.74 \\
\hline Bonita Point & BON & 105 & 710 & 1.24 & 1.78 & 1.62 & 0.71 & 1.97 & 1.88 & 0.76 & 1.00 \\
\hline MEAN (KJf) & & & 710 & 1.67 & 1.77 & 1.37 & 1.21 & 2.17 & 1.87 & 0.93 & 1.37 \\
\hline Presido & & 99 & 515 & 1.93 & 2.62 & 2.15 & 2.31 & 2.57 & 1.86 & 1.95 & 2.51 \\
\hline Golden Gate Bridge & GGB & 101 & 515 & 1.92 & 2.74 & 1.89 & 2.69 & 3.93 & 3.44 & 2.49 & 2.57 \\
\hline MEAN (sp) & & & 515 & 1.92 & 2.68 & 2.02 & 2.50 & 3.25 & 2.65 & 2.22 & 2.54 \\
\hline Berkeley (Lawrence Lab.) & BKL & 100 & 610 & 1.59 & 2.21 & 1.58 & 0.86 & 1.89 & 1.44 & 1.23 & 1,81 \\
\hline L 10 (Skyline Blvd.) & AP10 & 65 & 405 & 0.61 & 1.29 & 1.09 & 0.55 & 0.83 & 1.29 & 0.94 & 1.15 \\
\hline MEAN (TMZS ) & & & 508 & 1.10 & 1.75 & 1.33 & 0.71 & 1.36 & 1.36 & 1.08 & 1.48 \\
\hline APEEL 9 (Crys.Spr. Res.) & AP9 & 64 & 450 & 0.83 & 1.09 & 0.87 & 0.94 & 2.26 & 1.31 & 0.84 & 0.96 \\
\hline Rlchmond Clty Hall & $\mathbf{R C H}$ & 109 & 440. & 1.39 & 2.52 & 1.27 & 0.75 & 2.72 & 1.19 & 1.65 & 1.65 \\
\hline Saratoga & SAR & 33 & 440 & 4.12 & 2.19 & 4.25 & 5.35 & 2.62 & 1.58 & 1.63 & 1.66 \\
\hline SLAC & SLA & 54 & 420 & 1.72 & 1.26 & 1.32 & 4.11 & 2.21 & 1.08 & 2.19 & 2.31 \\
\hline MEAN ( OTs ) & & & 438 & 2.02 & 1.76 & 1.93 & 2.79 & 2.45 & 1.29 & 1.58 & 1.64 \\
\hline STANDAR & ATION & & 13 & 1.45 & 0.70 & 1.56 & 2.30 & 0.26 & 0.21 & 0.56 & 0.55 \\
\hline MEAN ("ROCK") & & & 596 & 1.41 & 1.48 & 1.38 & 1.51 & 1.73 & 1.53 & 1.21 & 1.34 \\
\hline STANDARD DEVIATION & & & 160 & 0.78 & 0.69 & 0.80 & 1.31 & 0.89 & 0.65 & 0.52 & 0.62 \\
\hline Hayward BART Station & HWB & 74 & 365 & 1.87 & 1.05 & 0.78 & 1.87 & 2.40 & 0.91 & 2.50 & 1.61 \\
\hline Oakland Offlce Bldg. & OOF & 93 & 305 & 5.51 & 2.94 & 1.30 & 3.50 & 4.34 & 2.80 & 2.45 & 2.75 \\
\hline Fremont & FRE & 58 & 285 & 1.22 & 0.80 & 0.45 & 2.57 & 1.72 & 0.55 & 1.89 & 1.15 \\
\hline Mission San Jose & MSJ & 57 & 285 & 1.45 & 1.44 & 1.57 & 2.15 & 1.73 & 1.04 & 1.06 & 0.86 \\
\hline Mult School (APEEL 2E) & MUR & 73 & 280 & 2.05 & 0.83 & 0.94 & 2.05 & 3.33 & 1.33 & 1.64 & 1.76 \\
\hline MEAN(Qpa) & & & 304 & 2.42 & 1.41 & 1.01 & 2.43 & 2.71 & 1.32 & 1.91 & 1.62 \\
\hline STANDARD DEV & ATION & & 35 & 1.76 & 0.89 & 0.44 & 0.65 & 1.13 & 0.87 & 0.60 & 0.73 \\
\hline Sunnyvale & SVL & 46 & 240 & 1.28 & 0.86 & 1.12 & 3.36 & 2.35 & 2.30 & 1.71 & 1.62 \\
\hline Agnew State Hosp. & ASH & 44 & 240 & 1.29 & 1.08 & 1.81 & 2.49 & 2.64 & 3.86 & 1.24 & 0.71 \\
\hline MEAN (Qhaf) & & & 240 & 1.28 & 0.97 & 1.47 & 2.92 & 2.50 & 3.08 & 1.48 & 1.17 \\
\hline MEAN ( Oal) & & & 286 & 2.10 & 1.29 & 1.14 & 2.57 & 2.65 & 1.83 & 1.79 & 1.49 \\
\hline STANDARD DE & & & 43 & 1.54 & 0.76 & 0.47 & 0.64 & 0.93 & 1.20 & 0.55 & 0.69 \\
\hline Emeryville Towers & ENT & 98 & $240^{\circ}$ & 235 & 2.44 & $0 . \pi 7$ & 5.13 & 6.11 & 2.50 & 2.54 & 3.08 \\
\hline Oakland Harbor Whart & OHW & 96 & 230 & 2.62 & 5.13 & 1.88 & 5.69 & 5.35 & 3.21 & 3.37 & 3.98 \\
\hline San Francisco Alrport & SF1 & 81 & 180 & 1.77 & 1.00 & 1.02 & 3.59 & 3.21 & 2.23 & 3.69 & 2.20 \\
\hline Maley Residence (F. Clty) & MAL & 68 & 150 & 1.29 & 0.63 & 0.35 & 0.88 & 1.09 & 1.05 & 0.82 & 1.11 \\
\hline APEEL 2 & AP2 & 66 & 130 & 1.39 & 1.30 & 0.46 & 1.61 & 2.32 & 1.12 & 2.37 & 3.21 \\
\hline Treasure Island & TRI & 99 & 130 & 0.60 & 0.28 & 1.04 & 3.13 & 2.85 & 4.12 & 2.06 & 2.36 \\
\hline Redwood Shores (F. Clty) & RSH & 67 & 115 & 1.74 & 1.44 & 1.59 & 2.36 & 2.57 & 2.25 & 2.57 & 2.57 \\
\hline MEAN ( Qat/Ohb & & & 168 & 1.68 & 1.74 & 1.02 & 3.20 & 3.36 & 2.36 & 2.49 & 2.64 \\
\hline STANDARD DEY & ATION & & 50 & 0.68 & 1.64 & 0.56 & 1.76 & 1.76 & 1.09 & 0.93 & 0.91 \\
\hline MEAN ("SOIL") & & & 156 & 1.89 & 1.52 & 1.08 & 2.89 & 3.00 & 2.09 & 2.14 & 2.07 \\
\hline STANDARD DEVIATION & & & 76 & 1.16 & 1.25 & 0.50 & 1.31 & 1.40 & 1.13 & 0.82 & 0.98 \\
\hline
\end{tabular}



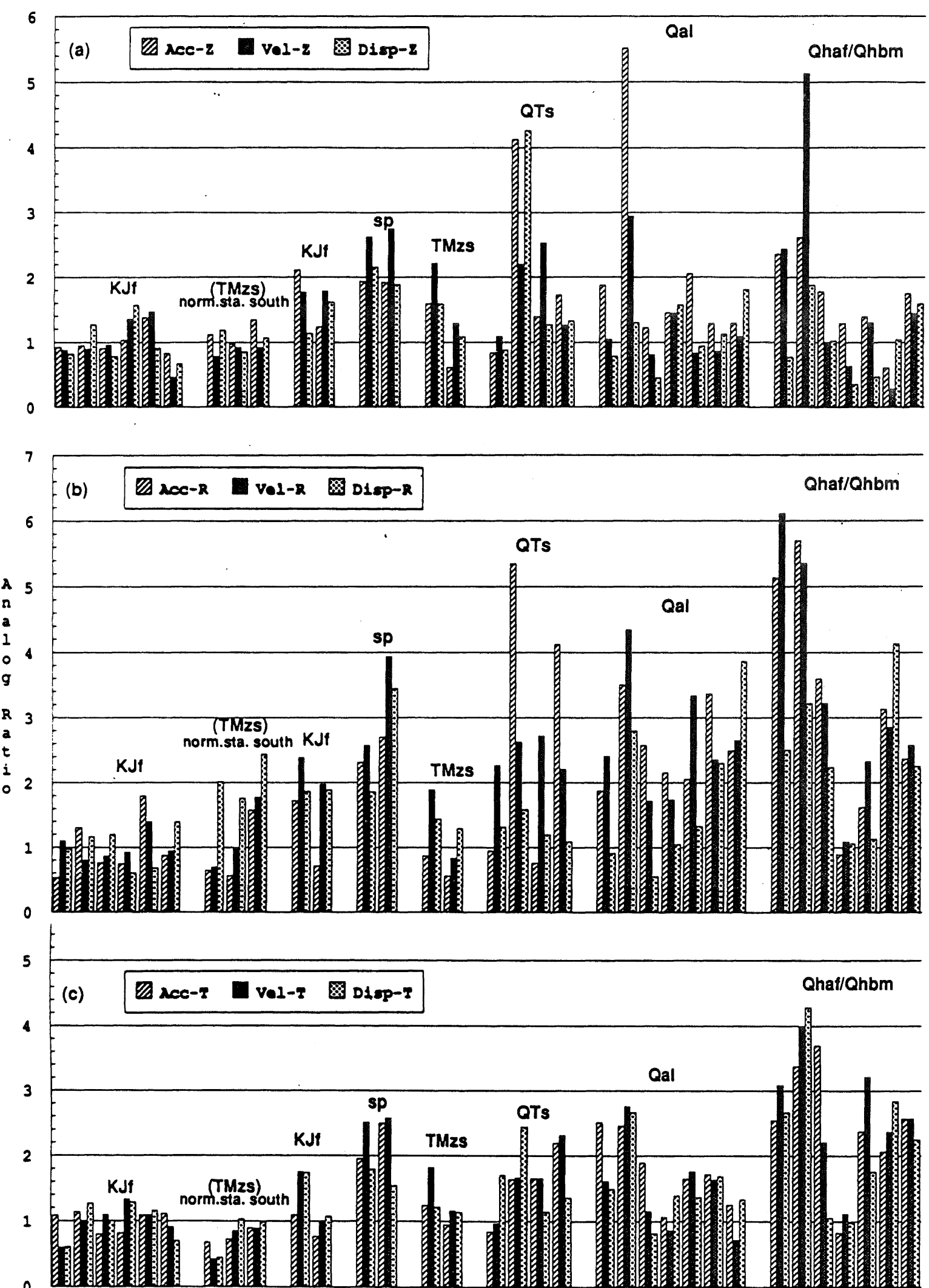

0

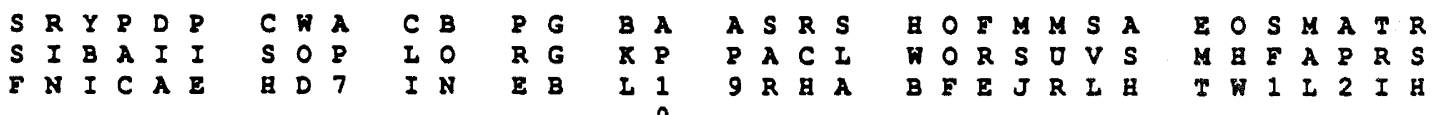

FIGURE 3 BAR CHARTS FOR RATIOS OF PEAR ACCELERATION, VELOCITY AND DI8PLACEMENT FOR THE VERTICAL (a), RADIAL (b), AND TRANSVERSE (c) COMPONENTS OF MOTION AS COMPUTED WITH RESPECT TO A "LOCAL ROCK" STATION AND ARRANGED ACCORDING TO GEOLOGIC UNIT FOR THE "FREE-FIELD" DATA FROM THE 1989 LOMA PRIETA EARTHQUAKE (FROM [7]). 


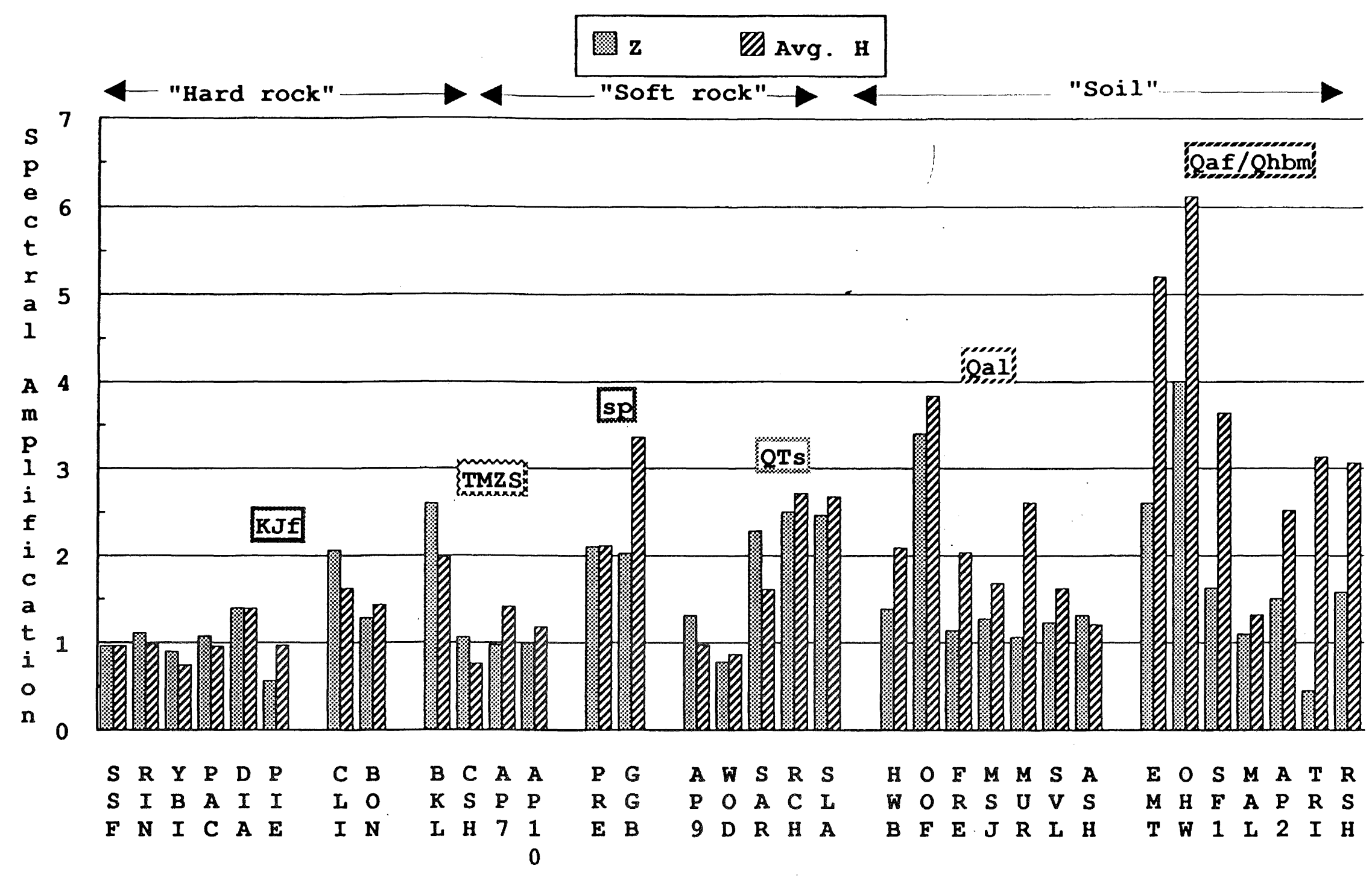

FIGURE 4 AVERAGE SPECTRAL AMPLIFICATION FOR THE VERTICAL AND AVERAGE HORIZONTAL GROUND MOTIONS AS COMPUTED FOR THE PERIOD BAND 0.4 TO 2.0 8ECONDS AS DETERMINED FROM RECORDINGS OF THE 1989 LOMA PRIETA EARTHQUARE AND ARRANGED ACCORDING TO TYPE OF UNDERLYING GEOLOGIC UNIT (BEE TABLE 1). THEY SHOW THAT IN GENERAL HORIZONTAL AMPLIFICATION EXCEEDS VERTICAL AMPLIFICATION AND INCREASES TITH DECREASING FIRMNESS OF THE DEPOSIT. 
recorded at low-strain levels exists for the San Francisco Bay region. These measurements provide an important data set for comparison with Loma Prieta strongmotion results to help resolve issues related to the amplification characteristics of local deposits at high strain levels. These weak-motion data, obtained prior to the Loma Prieta earthquake, include recordings of seismic waves generated by 1) 19 nuclear explosions in Nevada at distances near $400 \mathrm{~km}$ obtained at 99 sites, 2) the moderate (M5.3) 27 March 1957 earthquake observed at 5 sites, and 3) microtremors observed at 56 locations. In addition, empirical relations were derived for reliable intensity data for the California earthquake of 18 April 1906 as a function of distance from the surface rupture and type of geologic deposit [10].

This early work yielded many insights regarding the response of local geologic deposits. It established that seismic amplitude response of various local geologic deposits could be estimated with the influences of travel paths and source characteristics minimised. Resultant spectral analyses established the existence of resonant site periods for some "soil" sites with associated amplifications exceeding factors of 10-15 over narrow period bands. These data provided quantitative estimates of site response in terms of ratios of peak velocity and average spectral ratios for the period band 0.4-2 seconds (Tables 3,4 , and $5 ;[5]$ ). The weak-motion data showed that, in general, amplifications for horizontal motion in general exceed those for vertical motion, especially for sites on fill and or bay mud. A detailed comparison of these data with reliable 1906 intensity data [10] showed that a strong correlation existed between 1906 intensity increments and observed lowstrain amplifications. These relations together with detailed geologic mapping provided the basis for preparation of maps depicting regional variations in earthquake intensity for future large earthquakes in the San Francisco Bay region $[10,1]$.

In brief, conclusions previously derived from the low-strain or weak-motion data are consistent with those implied by the recent strong-motion data set. (See Borcherdt and Glassmoyer, [7] for a detailed comparison). In particular, mean amplifications derived from the two data sets for each of the initial six generalised geologic units are not statistically different at the $5 \%$ level of significance. Both data sets show the existence of resonant amplification at some sites and that average amplification (especially for horizontal motion) increases with decreasing firmness of the deposits. Because of the dominating influence of local geology, intensity maps prepared on the basis of low-strain data anticipated all of the areas in the San Francisco Bay region that experienced high intensities during the Loma Prieta earthquake. Detailed comparison of the results implied by the two data sets [7] indicates that more readily available weak-motion data provides general guidelines for levels of amplification that can be expected during damaging earthquakes and a useful basis for seismic zonation.
CHARACTERISATION OF GEOGRAPHIC VARIATIONS IN STRONG GROUND SHARING

Characterisation of potential variations in strong ground shaking throughout an urbanised region requires earth-science data available throughout the region of interest. In most regions, data most readily available is geologic data presented in the form of geologic maps. Most geologic maps, however, are compiled for purposes other than estimating ground response. For example, most geologic maps differentiate bedrock units in considerable detail, but only crudely differentiate young, unconsolidated sedimentary deposits of most concern for estimates of ground response. To develop a regional data base for mapping ground response, an extensive programme was undertaken to collect seismic velocity and geologic logs in all major sedimentary units in the San Francisco Bay region $[15,16,17]$ and the Los Angeles region [14].

Average amplifications (average horizontal spectral amplification, AHSA, 0.4-2.0 secs) derived from the recent set of strong-motion recordings of the Loma Prieta earthquake and the weak-motion data are plotted as a function of mean shear-wave velocity to a depth of $30 \mathrm{~m}$ (Figure 5). Preliminary empirical curves fit to the strong-motion Loma Prieta data (AHSA $=598 / V_{8}(\mathrm{~m} / \mathrm{s})$ and the weak-motion nuclear data (AHSA $=701 / V_{8}$ $(\mathrm{m} / \mathrm{s})$ using least squares also are shown. In general, the correlations derived between amplification and mean shear velocity for the two data sets are in good agreement. Some of the scatter in the data sets results from variations in material properties below $30 \mathrm{~m}$. A slightly smaller value for the Loma Prieta regression coefficient is due partly to energy reflected from the base of the earth's crust [7], and possibly to ground failures at two of the bay mud sites (AP2, TRI). The strong correlation between strong motion amplification and shear velocity and the good agreement in the two data sets imply that shear velocity and low strain ground response are useful predictors of strong-motion amplification at specific sites.

Delineation of various areas according to their capability to amplify strong ground motions requires extrapolation of sitespecific information, such as shear velocity and measured amplifications, to a regional scale on the basis of mapped geologic and geotechnical information. Previous studies $[8,12]$ established correlations between site-specific measurements of shear velocity at 59 boreholes [9-11], measured amplification at 99 sites [5], and mappable geologic, physical and geotechnical properties of the surficial materials in the San Francisco Bay region $[26,18]$. These correlations showed that the mappable materials in the San Francisco Bay region could be classified into some 13 categories with distinguishable seismic response characteristics [8]. Subsequent studies in the Los Angeles region at 84 borehole sites and some 100 amplification sites confirmed these classifications $[14,24]$. These correlations provide a preliminary classification of mapped surficial units in the San Francisco Bay region according to 

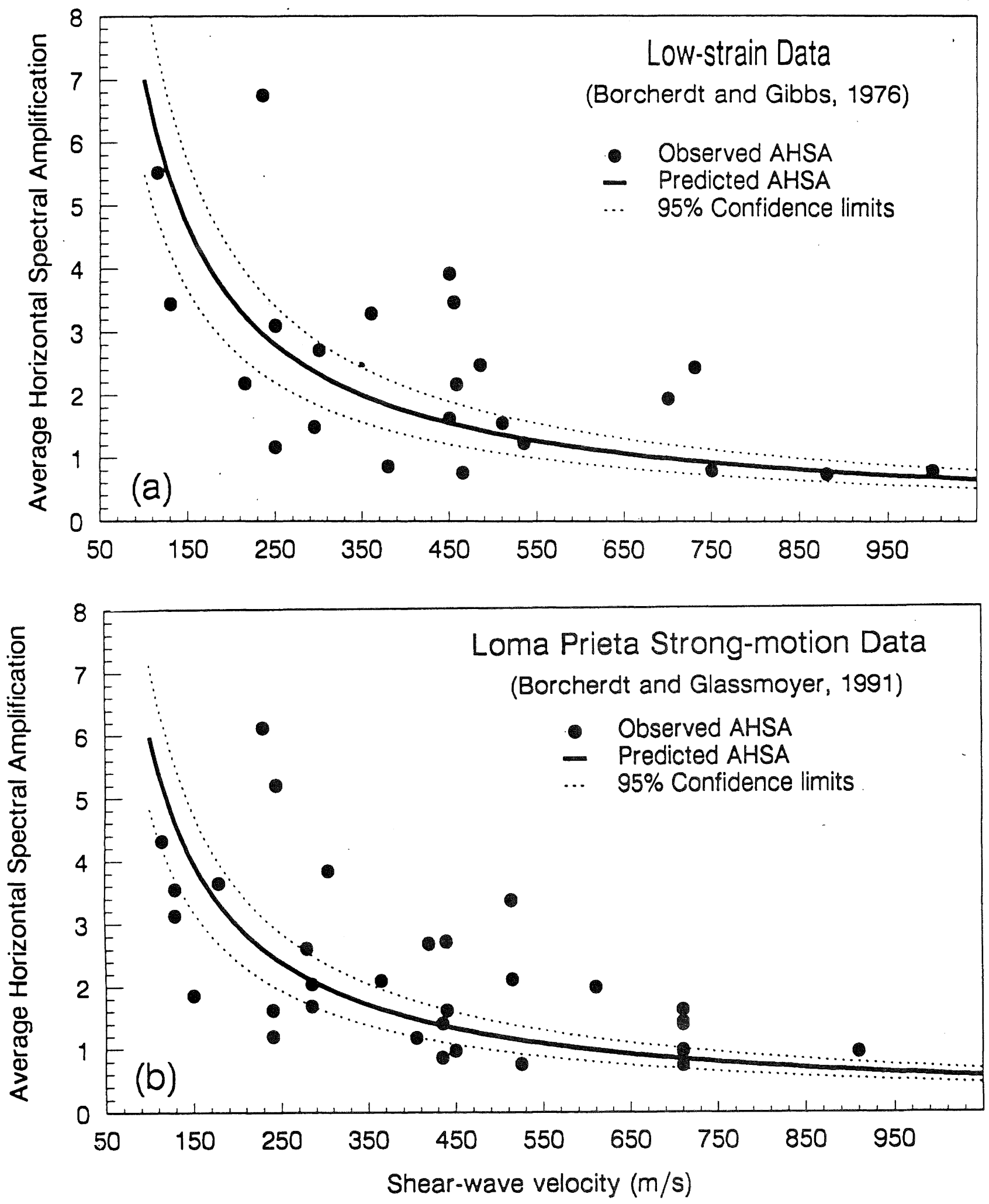

FIGURE 5 AVERAGE HORIZONTAL SPECTRAL AMPLIFICATION (AHSA) FOR (a) (LOP) LOW-STRAIN (NUCLEAR) DATA AND (b) (bOttom) LOMA PRIETA STRONG MOTION DATA AND CORRESPONDING REGRESSIONS AS A FUNCTION OF SHEAR VELOCITY $(V)$, (AHSA $=701 / \mathrm{V} ;$ AHSA $=598 / \mathrm{V}$, RESPECTIVELY). THEY SHOW THAT WEAK-MOTION DATA AND SHEAR-WAVE VELOCITY PROVIDE USEFUL GUIDELINES FOR PREDICTING AVERAGE AMPLIFICATION AT SPECIFIC SITES EXPERIENCING STRONG SHARING FROM FUTURE EARTHQUAKES. 
their general capability to amplify ground shaking (Table 2).

Justification for the classification of mapped geologic units into the categories shown in Table 2 is provided by plots of the statistics for amplification as a function of shear-wave velocity. The mean and the standard deviation limits for each category of mapped units are shown as derived from both the weak and strong-motion data sets (Figure 6a). The empirical curve for the larger weak-motion data set (Figure 5 a) is superimposed. The superimposed curve provides a good fit to the mean amplifications derived from the strongmotion recordings of the Loma Prieta earthquake. The strong correlations apparent between shear velocity and amplification indicate that the geologic classification of the units provides a means of anticipating potential variations in amplification on a regional scale.

As additional justification for the chosen classification of mapped units, intensity increments for the 1906 earthquake [10] are plotted versus average shear velocity measured at the site [12] (Figure 6b). (The intensity increments for each site were derived as the difference in intensity between that observed at the site expressed in terms of the San Francisco 1906 intensity scale and that predicted empirically for sites underlain by rocks of the Franciscan Formation (10]). Additional confirmation of consistency in empirically derived relations is provided by the superimposed mean curve for intensity increment versus shear velocity. This mean curve is predicted by substituting the empirical relations AHSA = $7_{01 v_{s}(m / s)}$ into the relation between intensity increment and amplification derived from weak motion data, namely $81=$ $0.27+2.70 \log$ [AHSA], [10]. The observed and empirically derived relations show a strong correlation with shear velocity. The strong correlation indicates that the classification of mapped units as described according to geologic and physical properties (Table 2) is a useful predictor of general geographic variations in earthquake intensity, depending on vulnerability of structures.

The plots shown in Figures 5 and 6 suggest that amplifications derived from either the weak or strong-motion data sets can be used to predict mean 1906 earthquake intensities. Concentrations of damage from the 1989 Loma Prieta earthquake in many of the same areas experiencing high intensity during the 1906 earthquake and those predicted previously using weak-motion data [10] confirm this conclusion.

Correlations established between seismic velocity, geotechnical descriptions, and measured amplifications in the Los Angeles region [14] showed that classifications of geologic units derived for the San Francisco Bay region were applicable elsewhere. Consequently, the classifications provided in Table 2 are expected to provide useful guidelines for urbanised regions with existing geologic but limited seismic data.

\section{PREDICTIVE GIS MAPPING OF POTENTIA} VARIATIONS IN STRONG GROUND SHARING

Modern Geographic Information Systems (GIS) afford important new opportunities to compile, archive and modify extensive spatial data bases for purposes of seismic hazard assessment. In particular, GIS technology provides powerful new tools to archive data pertaining to earthquake faults, distribution and character of geologic materials, topography, and watertable depth. These data, needed to map variations in ground shaking, liquefaction, landsliding, and water inundation, when incorporated with cultural information using GIS permit efficient assessment of seismic hazard. Applications of GIS to seismic zonation are discussed in detail by Wentworth and others [27]. A methodology for preparation of zonation maps for strong ground shaking using GIS is discussed here based on results presented by Borcherdt and others [11].

Vulnerability of man-made structures to earthquakes depends on the potential for earthquake shaking to reach critical levels sufficient to induce structural damage. The potential for shaking to reach critical levels is determined by the level of ground motion in the "base rock" at the site and the amount of amplification by near-surface geologic materials. Consequently, maps delineating critical levels that ground motions may be expected to exceed are comprised of maps anticipating levels of "base rock" motion and maps anticipating variations in amplification.

\section{opportunity Maps for Ground shaking on a Uniform Ground condition}

The opportunity for strong ground shaking to exceed some specified level for sites on a uniform ground condition, such as "bedrock", depends on the size, location, crustal attenuation characteristics, and frequency of occurrence of earthquakes. A variety of procedures exist to account for these factors in the form of predictive groundmotion maps for a uniform ground condition $[2,20]$. Such maps often depict contour levels that selected ground motion parameters will exceed with a specified return period. To maintain consistency with liquefaction mapping terminology [30], these maps are referred to here as opportunity maps for an excedent in ground shaking or, for brevity, excedent opportunity maps.

An example of a predictive map for earthquake intensity is shown for a central portion of the San Francisco peninsular (Figure 7). This map depicts contours for earthquake intensity assuming a uniform ground condition (firm to hard rock) for a repeat of the 1906 earthquake on the San Andreas fault. The contours were predicted using the attenuation relation derived from 1906 intensity data for sites underlain by rocks of the Franciscan complex (Intensity $=2.69-1.90 \log [$ distance $[\mathrm{km})] ; 1906$ S.F. scale, [10]). Specification of the contours in terms of a selected return period permits the map to be interpreted in terms of the probability (opportunity) for intensity to exceed specified levels. Similar maps also 
TABLE 2 CHARACTERIBATION OF GEOLOGIC UNITS ACCORDING TO AMPLIFICATION CAPABILITY BABED ON OBSERVATIONB OF AMPLIFICATION, INTENSITY INCREMENT, PHYSICAL PROPERTIEB, AND GEOLOGIC CHARACTERISTICS FOR MATERIALS IN AMPLIFICATION, INTENBITY INCREMENT, PHYSICAL PROPERTI
THE BAN FRANCIBCO BAY REGION, CALIFORNIA (AFTER [11]).

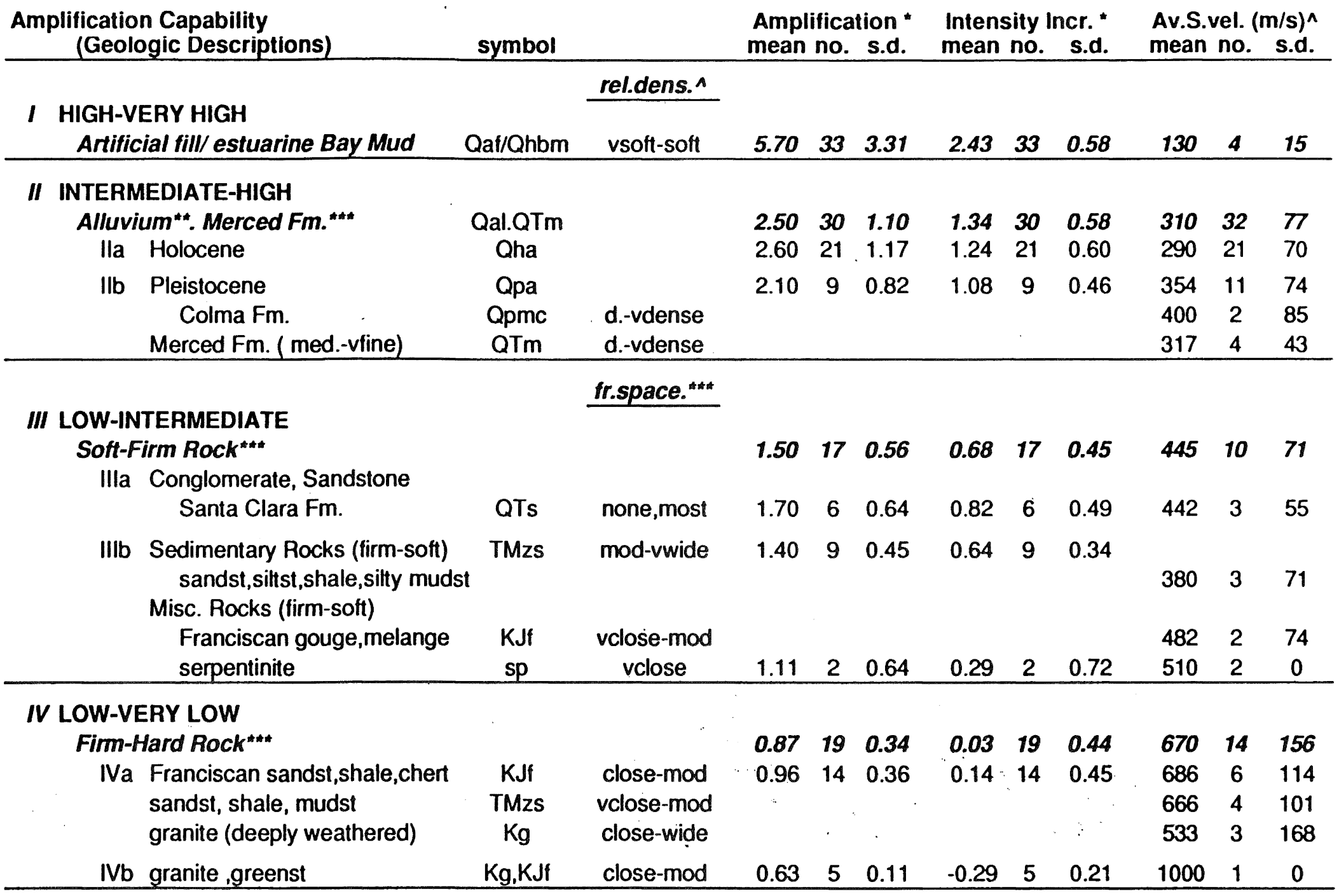

*[5], "*[18], ***[27], ^[12, $815,16,17]$ 

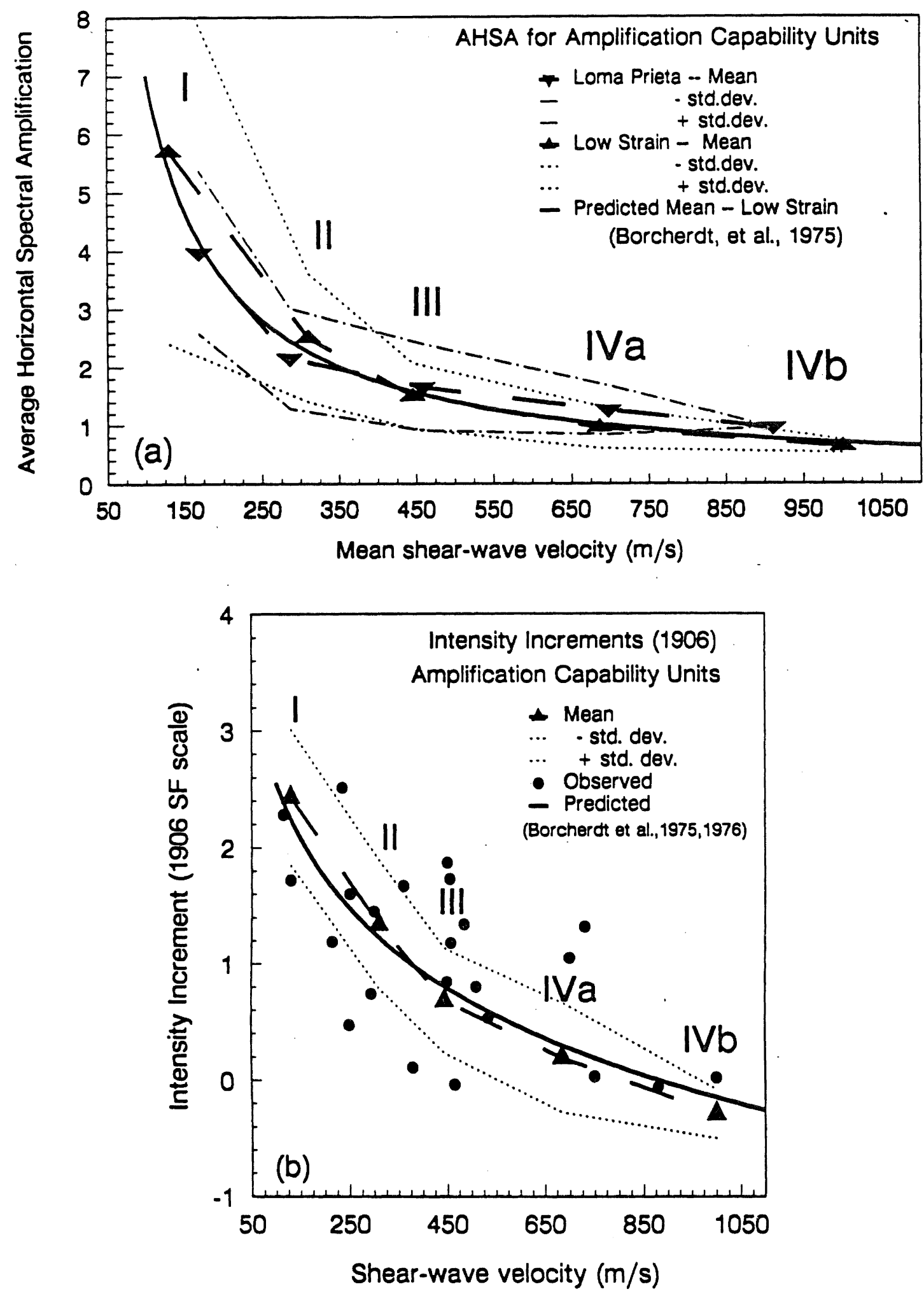

FIGURE 6 (a) (tOP) AVERAGE HORIZONTAL BPECTRAL AMPLIFICATION (AHBA) FOR AMPLIFICATION UNITS (TABLE 2) AS PREDICTED BY EMPIRICAL CURVE FOR LOW-BTRAIN DATA AND CALCULATED FOR THE LOW-8TRAIN AND 8TRONG-KOTION DATA 8ET8; (b) (bOttOM) INTENBITY INCREMENTS (1906) FOR INDIVIDUAL SITES AND PREDICTED INTENSITY-INCREMENT STATISTICS FOR EACH AMPLIFICATION CAPABILITY UNIT (TABLE 2; numbers 4-0 correspond to letters A-E of the san Francisco intensity scale). THE PLOTB HELP CONFIRY THE CLABsIFICATION OF UNITB ACCORDING TO CAPABILITY FOR AMPLIFICATION AB BHOWN IN TABLE 2 AND BHOW THAT THE MEAN AMPLIFICATION IN TERYS OF MEASURED GROUND MOTIONS OR EARTHQUAKE INTENSITY INCREABE WITH DECREABING BHEAR VELOCITY. 


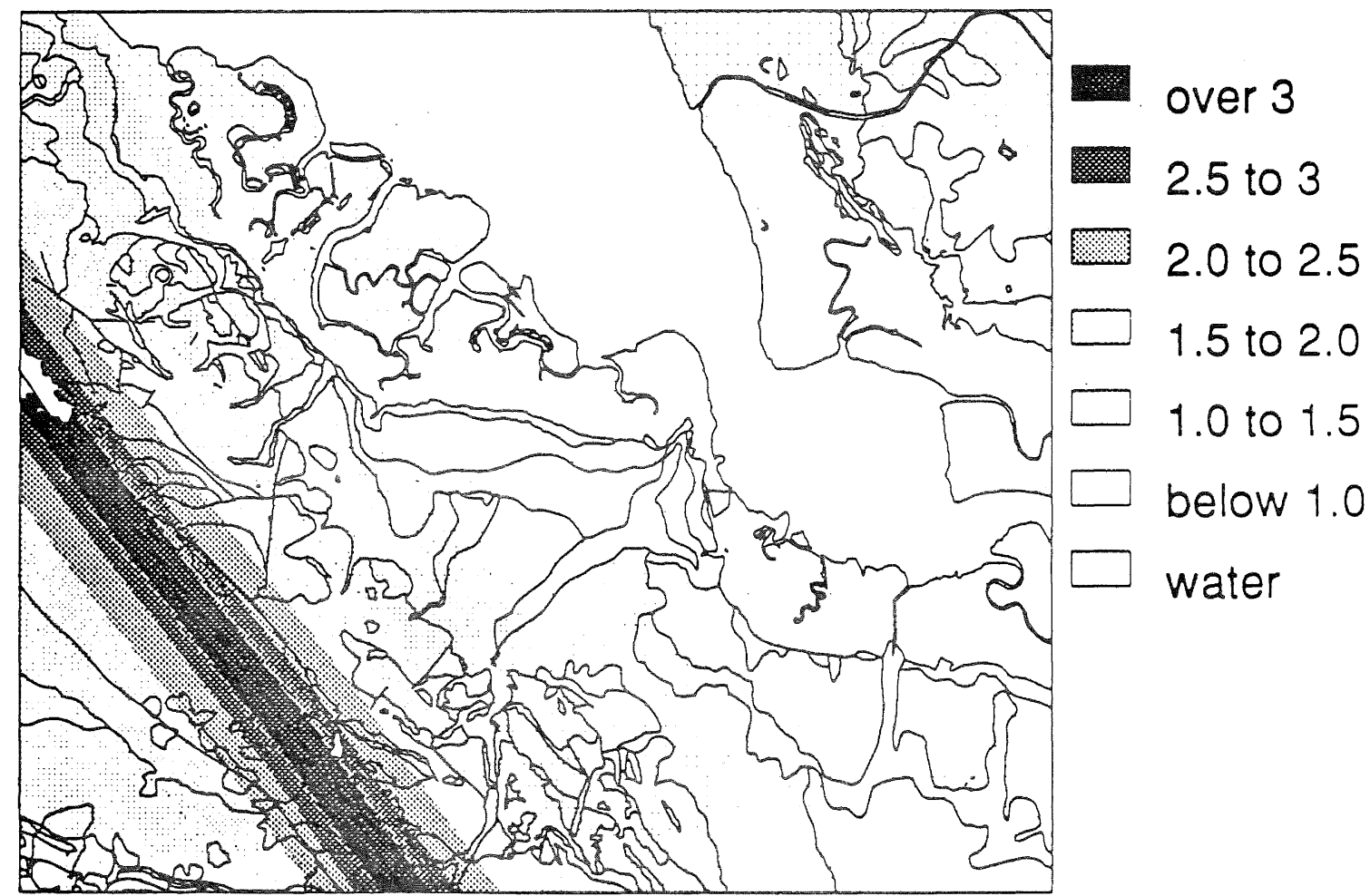

PIGURE 7 MAP SHOMING ZONES DELINEATED ACCORDING TO THE OPQORTUNITY THAT GROUND SHARING MAY EXCEED SPECIFIED LEVELS ON A UNIFORH GROUND CONDITION (FIRM TO HARD ROCK) FOR A REPEAT OF THE 1906 EARTHOUARE ON THE SAN ANDREAS FAULT. THE MAP ILLUSTRATES THE CONCEPT OF AN EXCEDENT OPPORTUNITY MAP. IT IS BAEED ON AN EMPIRICAL ATTENUATION RELATION DERIVED FROM RELIABLE 1906 INIENSIT\& DATA [10]. (Aumbers $4-0$ correspond to letters $A-E$ of the San Francisco intensity scale).

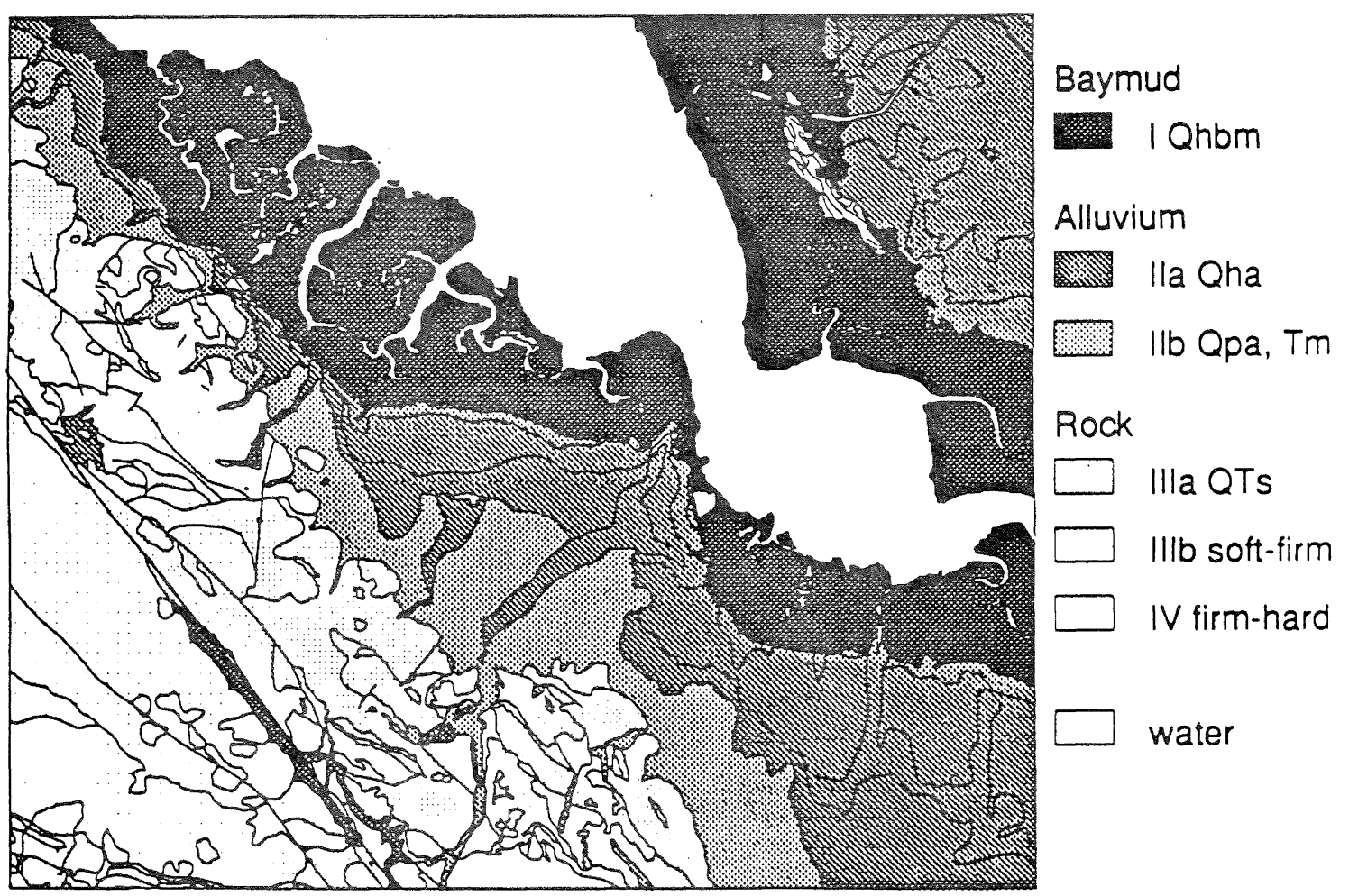

FIGURE 8 MAP SHOMING ZONES DELINEATED ACCORDING TO THEIR CAPABILITY TO AMPLIFY GROUND SHARING. THE MAP, TERMED HERE AN AMPLIFICATION CAPABILITY MAP, IS BASED ON THE CLAESIFICATION OF MAPPED GEOLOGIC MATERIAL UNITS PROVIDED IN TABLE 2. CAPABILITIES FOR AMPLIFICATION FOR ZONES I, II, III AND IV ARE CONSIDERED RESPECTIVELY TO BE HIGH-VERY HIGH, INTERMEDIATE-HIGH, LOW-INTERMEDIATE, AND LOW-VERY LOW. SUBCLASSIFICATIONS CORRESPOND TO GEOLOGIC DIFFERENTIATIONS WITH ONLY BLIGHT DISTINCTIONS IN AMPLIFICATION CAPABILITIES (SEE WENTWORTH et al. FOR MATERIALS MAP [28]). 
can be produced for other ground motion parameters such as peak acceleration, peak velocity or pseudo-spectral response parameters. Such maps can be readily generated with GIS.

\section{Amplification Capability Maps for Ground shaking}

The capability of local geologic deposits to amplify strong ground shaking depends on the physical properties of the materials as well as their three-dimensional geometrical distribution. Detailed information on the three-dimensional distribution of materials is generally not available throughout a region in sufficient detail to be incorporated into maps showing variations in ground response. Consequently such maps must necessarily be based on the distribution of geologic materials as mapped at the surface. Interpretations of the resultant maps must necessarily account for these limitations.

The classification of mapped geologic units as specified in Table 2 provides the basis for preparation of maps showing amplification capability. An example for a portion of the San Francisco Bay region is shown in Figure 8 . This map was prepared on the basis of physical property attributes used to differentiate some 38 units in the San Francisco Bay region (see wentworth and others, [27] for derivative maps). The physical property attributes as specified in Table 2 were used together with specified unit classifications to differentiate resultant zones.

The map shown in Figure 8 is intended to identify zones according to their generalised capability to amplify ground motion as quantified in terms of earthquake intensity. The map is intended to ascribe general levels of amplification capability ranging from high to very high for areas underlain by bay med to low to very low for areas underlain by firm to hard rock. The maps are not intended to predict actual ground motion amplification at specific sites, but instead to indicate areas that if underlain by sufficient thicknesses of mapped surface materials are likely to experience amplifications commensurate with those specified by the corresponding statistics in Table 2 . The maps serve to identify areas for which ground motion amplification may be a problem and special studies should be undertaken to develop more precise predictions.

Maps as defined in Figure 8 and termed amplification capability maps are similar in concept to liquefaction susceptibility maps [31]. Both maps are based on the same geologic maps [18]. Incorporation of data on water-table depth permits the capability map to be interpreted in terms of liquefaction susceptibility [28]. In the San Francisco Bay region the distribution of bay mud deposits in relation to depth of water table as determined by sea level is such that mapped zones of highest liquefaction susceptibility are also zones assigned highest amplification capability [28].

\section{Potential Kaps for Ground shaking}

The potential for strong ground shaking to exceed a specified level depends on the opportunity for input motions on a standard ground condition to exceed a particular level and the capability of local deposits to amplify incoming motions. Consequently, maps showing the potential for an excedent in strong motion represent the composite or superposition of maps showing excedent opportunity and amplification capability. Empirical relations for attenuation and amplification capability classifications (Table 2) provide a rigorous basis for preparation of such maps.

An example of a map showing potential variations in earthquake intensity is shown (Figure 9). This map was constructed as a composite of the intensity map for a uniform ground condition (firm to hard rock, Figure 7) and the amplification capability map (Figure 8). Incorporation of information on the probability of occurrence permits the map to be interpreted in terms of the potential for an excedent in earthquake intensity for an earthquake similar to the 1906 earthquake on the San Andreas fault. In order to maintain consistency with liquefaction terminology [31], these maps are designated here as potential maps for an excedent in ground shaking or for brevity excedent potential maps for ground shaking.

The map for earthquake intensity associated with a repeat of the 1906 earthquake (Figure 9) indicates that damage to vulnerable structures will vary from weak to very violent depending on distance of the area from the causative fault and type of underlying geologic deposit. Specifically, the map suggests that damage in the urbanised regions away from the immediate vicinity of fault rupture will be concentrated primarily in areas underlain by fill and bay mud. The maps indicate that on the average intensities can be expected to 2.4 units larger and range up to 3.0 units larger on bay mud than on rock sites at comparable distance. Inspection of the intensities ascribed in San Francisco for the Loma Prieta earthquake [23] shows a similar variation of 3 units in intensity for sites on fill/bay mud in San Francisco when compared to the lowest intensities ascribed to sites on the Franciscan Complex. These consistencies in predicted and observed intensity variations for sites on soft deposits suggest that such maps are useful for identifying areas most vulnerable to future earthquake losses and, in turn, those areas requiring special studies.

Excedent potential maps for other ground shaking parameters such as peak velocity and pseudovelocity response may be derived for a specified return period in a similar fashion. The amplification capability map as specified by Table 2 is applicable to parameters largely dependent on ground motion characteristics in the period band $0.4-2 \mathrm{sec}$.

Excedent potential maps provide an improved basis for assessing liquefaction and landslide susceptibility $[9.30,31]$. The account for the amplification capability of 


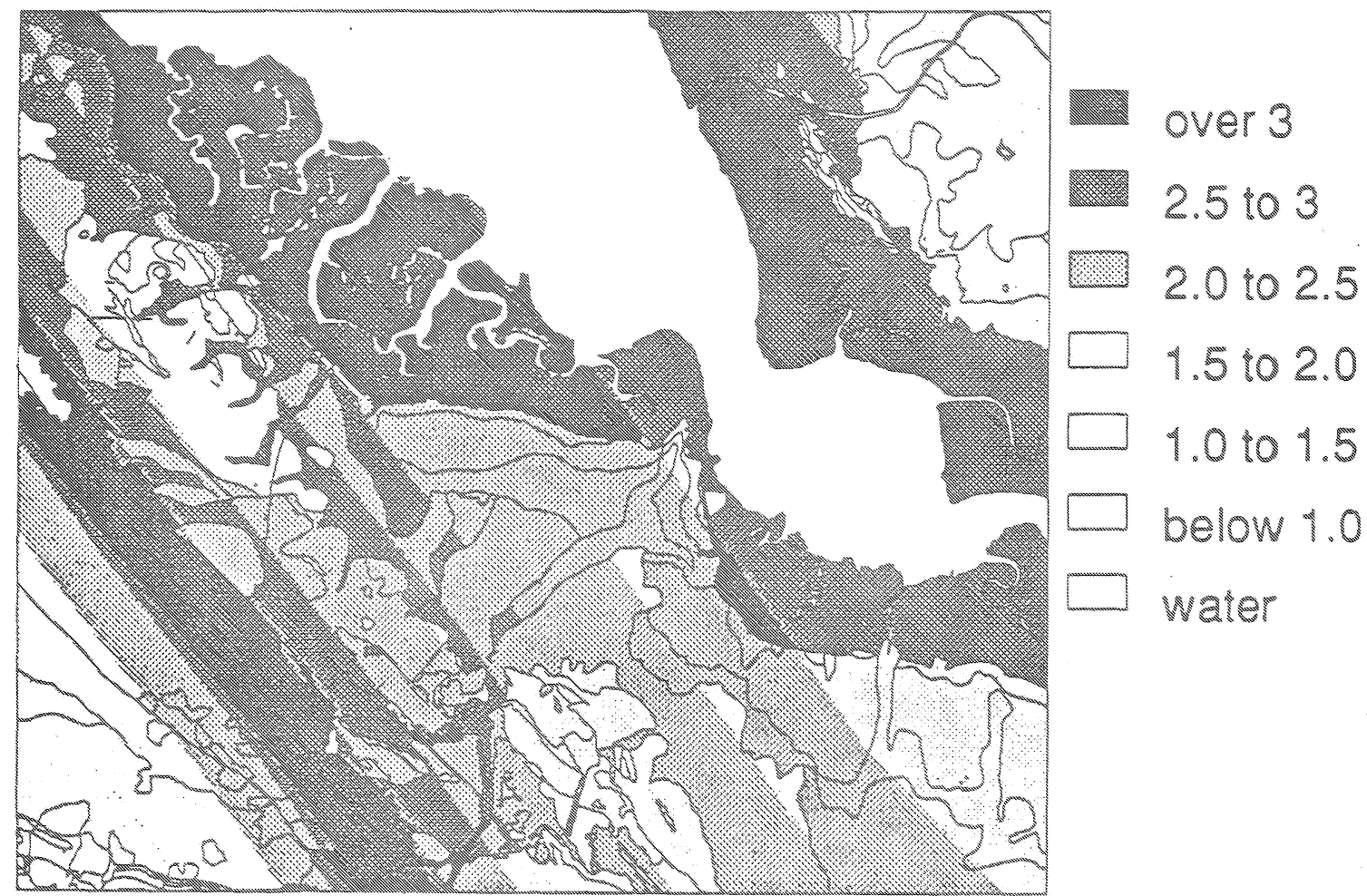

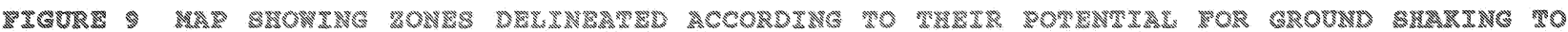

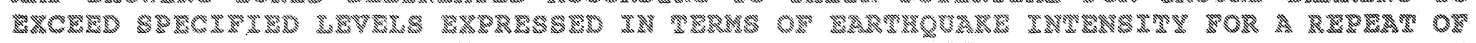
THE 2006 FAR

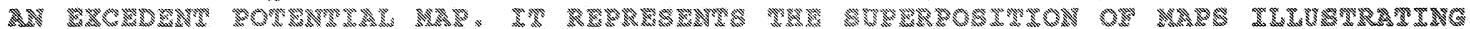

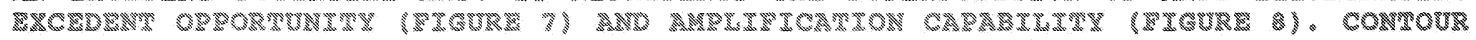

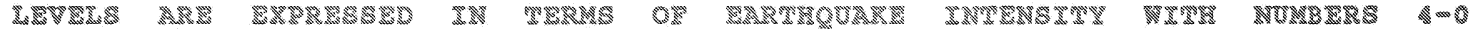

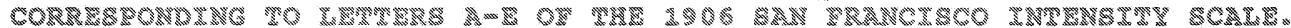

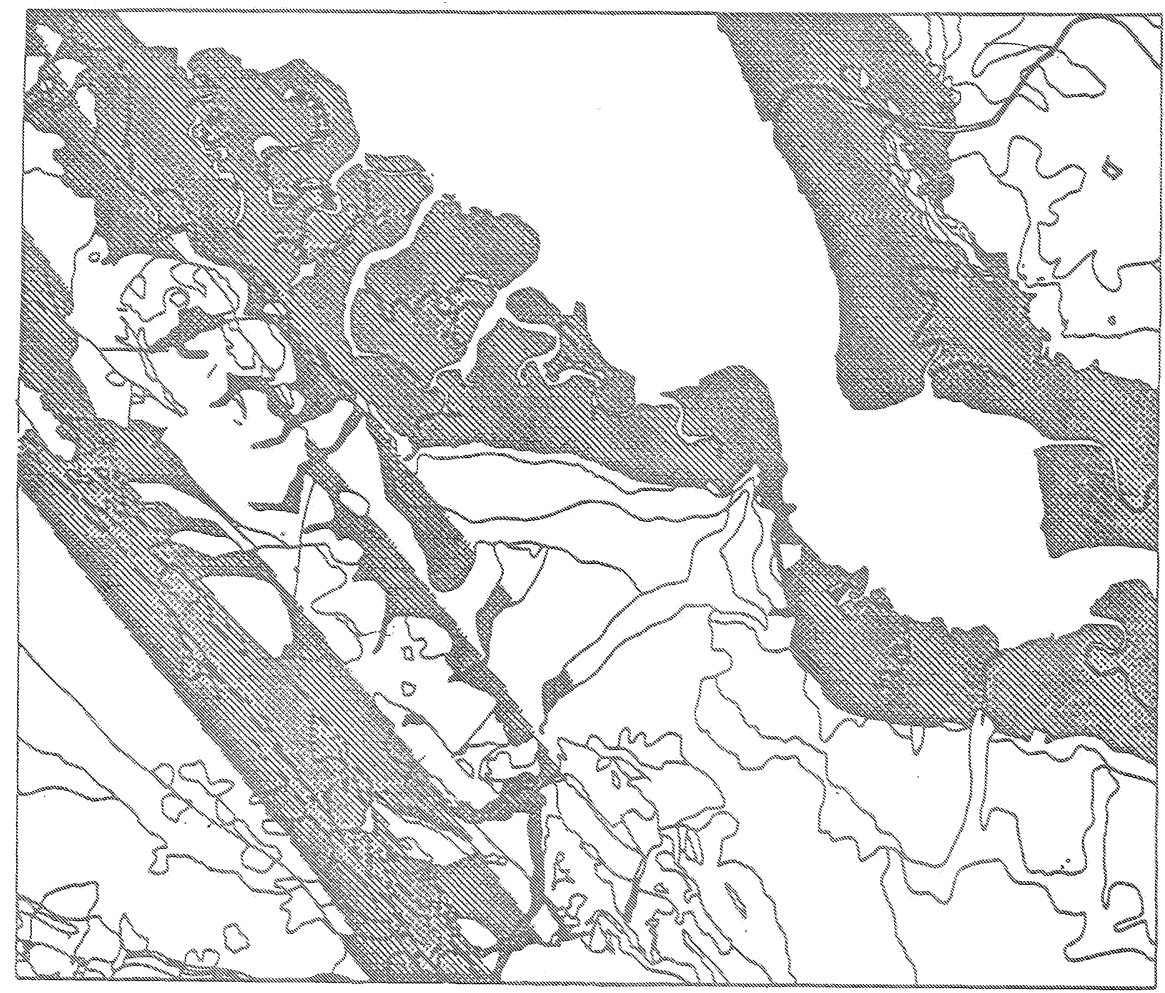

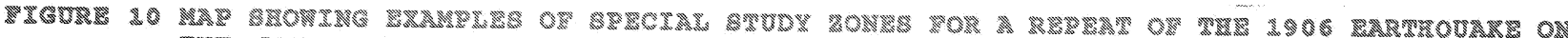

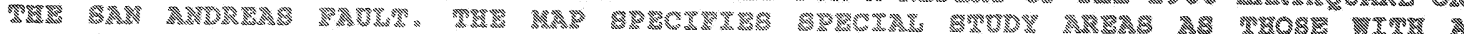

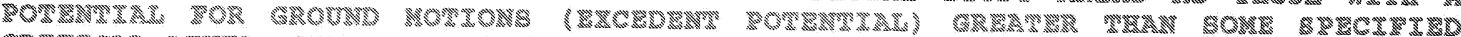

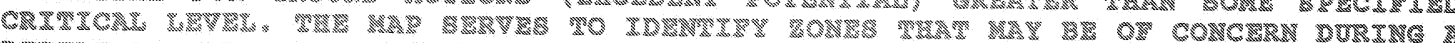

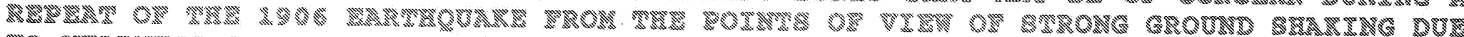

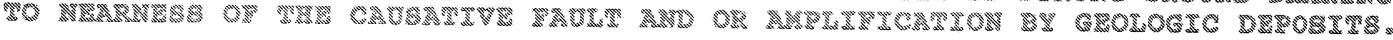


local deposits and can be used to replace previous maps which assume a uniform ground condition usually selected as "bedrock" [31].

\section{special study zone Maps for Ground shaking}

Recent legislation for the state of California (Seismic Hazards Mapping, Act $A B$ 3897,1990 ) mandates that guidelines and priorities be established for preparation and utilisation of maps delineating special study zones for strong ground shaking, liquefaction, and landsliding. Such maps and corresponding policies for interpretation are an important new mechanism for implementation of improved hazard mitigation measures.

Maps showing the potential for an excedent in various ground shaking parameters or earthquake intensity (eg, Figure 9) readily lend themselves to the definition of special study zones. The maps can be used to define rigorously zones based on selection of some critical level of excedent potential. Selection of this critical level permits zones with an excedent potential higher than the selected level to be designated as special study zones. Special study zone maps derived in terms of peak ground motion parameters permit straightforward interpretation in terms of building codes. Maps prepared on the basis of earthquake intensity facilitate interpretation for purposes of land-use planning and interpretation by the general public.

To illustrate methodology, a map, indicating a possible definition of special study zones, for a portion of the San Francisco Bay region is shown (Figure 10). This map is prepared using GIS from the map used to illustrate excedent potential for earthquake intensity (Figure 9). The map was derived by specifying a critical level for intensity at the midpoint between levels of very strong and violent on the 1906 intensity scale. Specification of this critical level in GIS permitted all polygons on the map with an assigned intensity attribute higher than this value to be designated as special studies zones. GIS readily permits generation of such maps and analysis of the implications of various selected critical levels.

Maps showing special study zones define areas of most concern for consideration of the potential effects of strong ground shaking. Such maps indicate that zones near the causative earthquake source, zones underlain by fill and bay mud and zones at intermediate distances with mapped surficial materials having some amplification capability, are special study zones. Selection of a conservative value for the critical level serves to identify most areas for which damaging effects of strong ground shaking are likely to be of concern due to soil amplification. For many sites, additional investigation may reveal that sufficient thickness of "soil" does not exist for the site to be of concern. For other sites, special land-use or design practice may be indicated by further investigation. Clearly, for special study zone maps to be effective in mitigating earthquake hazards, policies regarding type of site investigation and mitigative measures must also be implemented.

\section{GENERAL CONCLUSIONE}

Damage from the 1989 Loma Prieta and 1906 California earthquakes was concentrated in areas underlain by soft soil deposits similar to damage concentrations observed in numerous other historic earthquakes. For the 1989 earthquake, damage percentages for unreinforced masonry structures were 7-8 times larger on soft soil sites than on rock sites. Recordings of strong horizontal ground motion were 2-6 times larger on soft soil deposits. Consistent correlations between measured weak and strong-ground motion amplifications, intensity, shear velocity, and geologic characteristics provide a characterisation of a wide range of deposits according to inherent amplification capabilities. Similar studies conducted in the Los Angeles region of California indicate that this classification is applicable to other regions. This consistency suggests that the classification is useful in other urbanised areas with geologic but limited seismic data.

GIS technology provides a powerful tool to archive and update spatial data bases, readily incorporate empirical relations, and produce maps useful for hazard mitigation. Maps prepared showing ground shaking potential for a standard ground condition. amplification capability, ground shaking potential accounting for variations in nearsurface geology, and special study zones illustrate a logical framework for seismic zonation. Such maps, based on geologic data available in many areas, provide a rigorous basis for cost-effective mitigation of earthquake hazards in urbanised seismic regions of the world.

\section{ACXNOWLEDGEMENTS}

This case study, based on the observation and analyses of data collected over a period of more than two decades, could not have been conducted without the help and support of numerous co-authors and colleagues indicated on previous publications. In particular, recent results concerning the application of GIS could not have been obtained without the significant and ongoing efforts of $C$ Wentworth, $T$ Fitzgibbon, $R$ Mark and $P$ showalter in developing extensive GIS data bases. Their assistance together with that of A Janssen was crucial to the production of GIS maps shown here. Comprehensive reviews by Robert D Brown, Jr., Arthur F MCGarr and A Gerald Brady are appreciated. C Ramseyer and $M$ Dowd graciously and expertly assisted with transformation of the draft into camera ready copy.

\section{REFERENCES}

1 ABAG. 1982. Using earthquake intensity and related damage to estimate earthquake intensity and cumulate damage potential from earthquake ground 
shaking. Working paper 17. Berkeley, California.

Algermissen, S.T., Perkins, D.M., Thenhaus, P.C., Hansen, S.L. and Bender, B.L., 1982. Probabilistic estimates of maximum acceleration and velocity in rock in the contiguous US US Geological Survey Professional Paper 82-1933.

Borcherdt, R.D., 1970. Effects of local geology on ground motion near san Francisco Bay, Bulletin Seismological Society of America 60: 29-61.

Borcherdt, R.D., 1990. Influence of local geology in the San Francisco Bay region, California on ground motions generated by the Loma Prieta earthquake of 1 October, 1989 in Proceedings International symposium on safety of Urban Life and Facilities. Tokyo Institute of Technology. Tokyo, Japan.

Borcherdt, R.D. and Gibbs, J.F., 1976. Effects of local geological conditions in the San Francisco Bay region on ground motions and the intensities of the 1906 earthquake, Bulletin Seismological Society of America 66: 465-500.

Borcherdt, R.D. and Glassmoyer, G., 1990. Local geology and its influence on strong ground motion generated by the Loma Prieta earthquake of 17 October 1989, in Proceedings National Conference on the Loma Prieta Earthquake one Year Later. Association of Bay Governments. Oakland, California.

7 Borcherdt, R.D. and Glassmoyer, G. , 1991. On the characteristics of local geology and their influence on ground motions generated by the Loma Prieta earthquake in the San Francisco Bay region, Bulletin Seismological Society of America (submitted).

8 Borcherdt, R.D., Gibbs, J.F. and Fumal T.E., 1978. Progress on ground motion predictions for the San Francisco Bay region, California, in US Geological Survey Circular 807 . Also, Proceedings Second International Conference on Microzonation Safer Constr. Research, Appl. 2, 1: 13-25.

9 Borcherdt, R.G., ed., 1975. Studies for seismic zonation at the san Francisco Bay region. US Geological Survey Professional paper 941-A.

10 Borcherdt, R.D., Gibbs, J.F. and Lajoie, K.R. 1975. Prediction of maximum earthquake intensity in the San Francisco Bay region, California for large earthquakes in the San Andreas and Hayward faults. US Geological Survey Miscellaneous Field studies Map $M F-709$.

11 Borcherdt, R.D., Wentworth C.M., Janssen, A., Fumal, T. and Gibbs, J.F. 1991. Methodology for predictive GIS making of special study zones for strong ground shaking in the san Francisco Bay region, $\mathrm{CA}$ in Proceedings Fourth International Conference on Seismic zonation. Stanford, California.

12 Fumal, T.E. 1978. Correlations between seismic wave velocities and physical properties of geologic materials in the San Francisco Bay region, California, US Geological Survey Open-File Report 78-1067.

13 Fumal, T.E. 1991. Shear-wave velocity estimates and site geology for strongmotion recordings sites of the Loma Prieta earthquake of 17 October 1989. US Geological Survey Open-File Report, in press.

14 Fumal, T.E. and Tinsley, J.C. 1985 Mapping Shear-wave velocities of near surface geologic materials. US Geological Survey Professional Paper 1360 .

15 Gibbs, J.F., Fumal, T.E. and Borcherdt, R.D. 1975. In-situ measurements of seismic velocities at twelve locations in the San Francisco Bay region. US Geological Survey open-File Report 75564.

16 Gibbs, J.F., Fumal, T.E. and Borcherdt R.D. 1976. In-situ measurements of seismic velocities in the San Francisco Bay region-Part II. US Geological Survey Open-File Report 75-731.

17 Gibbs, J.F., Fumal, T.E. and Borcherdt, R.D. 1977. In-situ measurements of seismic velocities in the San Francisco Bay region-Part III. US Geological Survey Open-File Report 77-850.

18 Helley, E.J. and Lajoie, K.R. 1979 Flatland deposits of the San Francisco Bay region, California - their geology and engineering properties and their importance to comprehensive planning. US Geological Survey Professional Paper 943.

19 Holmes, W.T., Lizundia, B., Brinkman, S., Conrad, J., Reitherman, R., Dong, W., Burton, J., and Bailey, A. 1990, Preliminary report on damage unreinforced masonry buildings. The Loma Prieta Earthquake Report. Rutherford and Chekene, San Francisco, California.

20 Joyner, W.B and Fumal, T.E., 1985. Predictive mapping of earthquake ground motion. US Geological Survey Professional Paper 1360.

21 Kanamori, H. and Satake, K. 1989. Broadband study of the 1989 Loma Prieta earthquake, Geophysical Research Letters 17: 1179-1182.

22 Lawson, A.C. 1908. The California earthquake of 18 April 1906. The State Earthquake Commission Report. Carnegie Institute, Washington. 
23 Pflaker, G. and Galloway, J.D. 1989. Lessons learned from the Loma Prieta, California, earthquake of 17 October 1989. US Geological Survey. Circular 1045.

24 Rogers, A.M., Tinsley. J.C., and Borcherdt, R.D. 1985 . Predicting relative ground response. US Geological Survey. Professional Paper 1360 .

25 Seed, R.B., Dickenson, S.E., Riemer M.F., Bray, J.D., Sitar, N., Mitchell, J.K., Idriss, I.M. Kayen, R.E., Kropp, A. Harder, L.F., Jr., and Power, M.S. 1990. Preliminary report on the principal geotechnical aspects of 17 october 1989 Loma Prieta earthquake. University of California Berkeley. Report UCB/EERC-90/05.

Sommervilie, P. and Yoshimura, J. 1990. The influence of critical Moho reflections on strong ground motions recorded in San Francisco and Oakland during the 1989 Loma Prieta earthquake, Geophys. Res. Lett. 17, 1203-1206.
Wentworth, C.M., Ellen, S., Frizzell, Jr., V.A., and Schlocker, J. 1985. Map of hillside materials and description of the engineering character, San Mateo county, CA. US Geological Survey. Professional Paper 1357.

28 Wentworth, C.M., Borcherdt, R.D., Fitzgibbon, T.T., and Showalter, P.K. 1991. Application of GIS technology to seismic zonation of the San Francisco Bay region. Proceedings Fourth International conference on seismic zonation. stanford, California.

29 Wood, H.O. 1908. Distribution of apparent intensity of San Francisco in the California earthquake of 18 April 1906. The state Earthquake Commission. Report. Washington DC Carnegie Institute publication 87: 220-245.

30 Youd, T.L., Nichols, D.R., Helley, E.J., and Lajoie, K.R. 1975 Liquefaction potential, in studies for seismic zonation of the San Francisco Bay region. US Geological Survey. Professional Paper 941-A.

31 Youd, T.I. and Perkins, D.M. 1978. Mapping liquefaction-induced ground failure potential, ASCE Journal, Geotechnical Engineering Division 104: 433-446. 